\title{
A Corpus-Based Analysis of Tertiary Students' Communication Strategies
}

\author{
Elyssa Kay V. Martinez \\ Instructor, Surigao Del Sur State University, Tandag, Philippines
}

\begin{abstract}
Students who experience dearth in their linguistic resources, particularly in English, do not just deploy a single type of communication strategy during breakdowns in communication, but rather a combination of several CSs that manifests their strategic competence in communication. This study is geared to assess what, how, and why communication strategies were deployed. To support this assertion, a corpus-based method was used to collect and analyze corpus elicited from 158 tertiary students through oral interviews and focused-group discussions. Identified CSs were further given quantitative analysis based on how many times the strategies appeared in the students' responses. Findings revealed six major categories of CSs which include fifteen sub strategies of which 'filler' as a 'time stalling strategy' was found to be the dominant among others such as topic avoidance, message abandonment, circumlocution, gesturing, restructuring, code switching, lengthened sound, repetition, self-initiated repair, appeals for help, adaptors, mumbling, and omission.
\end{abstract}

KEY WORDS: strategic competence, communication strategies, sub strategies

\section{INTRODUCTION}

Communication strategies are considered to be important aspects of communicative competence which must be integrated into the other components that comprise it (linguistic, sociolinguistic, and discourse) (Canale \& Swain, 1980). Thus, communication is not just about the speaker's knowledge in grammar and sociolinguistics, but it is also of the speaker's ability to communicate his thoughts in the face of difficulties. This has led the researcher to investigate on the students' strategic competence which aims to whether prove or disprove that students who lack linguistic resources deploy communication strategies when faced with communication breakdowns.

Canale \& Swain (1980) define strategic competence as the knowledge of verbal and non-verbal communication strategies that are recalled for breakdowns in communication. Spromberg (2011) highlights Dorneyei and Thurell's (1991) concept of strategic competence as an 'ever-present, potentially usable inventory of skills that allows a speaker to negotiate messages and resolve problems, or to compensate for deficiencies in any of the underlying competencies. Thus, using CSs enable speakers to overcome difficulties in communication (CelceMurcia, et al., 1995).

L2 speakers experience certain limitation when communicating in a language which is not of their own due to their lack of linguistic resources (Faerch \& Kasper 1978). It is in this perspective that speakers need to learn how to regulate and modify speech within a conversation so that they could plan, select appropriate words, and reduce complexity of utterances (Blum \& Levenston, 1978). Ability to regulate and modify speech is performed by strategically competent speakers. However, despite national and international researches have been conducted on this area of study, skills that are supposed to address problems during communication are given minimal attention in the region where the study has been conducted.

Established perspectives of authors and gaps to be addressed through this investigation are highly associated with problems which are usually deficits in the other underlying components of communicative competence. Appropriate and relevant design of skills trainings can only be done when problems are clearly 
determined and defined. So that future researches can arrive to the design of skills training appropriate for the strengthening of strategic competence, this study will embark on identifying what CSs are employed by L2 students and when they are likely recalled to compensate for deficits. An inventory of CSs, through this investigation, will help in determining students' limitations in oral communication; by doing so, future researches can properly address such limitation through appropriate and relevant skills trainings.

\section{Research Methodology}

The corpus-based method was used to collect and analyze students' strategic competence through the appearance of communication strategies in their utterances. Students engaged in speech-making processes to gather data through scheduled oral interviews and focused group discussions (FGD). A 00:02:19 video clip was used to elicit the utterances during the oral interviews and the FGD provided the respondents opportunities to express what happened, why they did base on how they felt about the entire experience (the contents of the video, their limitations, and etc.). In the selection of the respondents, the stratified purposive sampling was used. The criterion sampling, which made the technique purposive, was done to limit and sufficiently represent the all the colleges in SDSSUmain campus; mainly, the respondents were enrolled in oral communication courses. However, there was a need to reduce the 333 students who qualified for the set criterion, hence the stratified random sampling was used. A total of 158 tertiary students with different fields of specialization and year levels, enrolled in oral communication were the respondents of the study.

Responses were recorded, transcribed, analyzed, tagged, tallied and treated. Frequency counts were used as the statistical treatment to determine the number of instances when CSs occurred during the speech-making processes. Results of the treatment were tabulated and interpreted.

\section{Results and Discussion}

Results revealed a tally of sixteen communication strategies used by tertiary students who were nonnative speakers of English. Presented in the table below are identified communication strategies distributed into various categories according to how and when they are used in communication. According to Cabaysa and Baetiong (2010), affective factors have a powerful impact on language learning wherein the anxiety of learners led to withdrawal from the learning experience. Based on the derived responses, several factors related to the students' experienced deficits were associated to anxiety which led them to either take risks and utilize available language resources or withdraw from the learning experience.

The communication strategies employed by the students are divided into four categories which were described using the taxonomy of communication strategies of Celce-Murcia, Dorneyei, and Thurell (1995) and Dorneyei and Scott (1998).

Table1. Communication Strategies of Tertiary Students

\begin{tabular}{|c|c|c|c|c|c|c|}
\hline \multirow{2}{*}{ Strategies } & \multirow{2}{*}{ Description } & \multirow{2}{*}{ Sample Responses } & \multirow{2}{*}{$\mathbf{F}$} & \multirow{2}{*}{$\mathbf{P}$} & \multicolumn{2}{|c|}{ Rank } \\
\hline & & & & & C & $\mathrm{C}_{2}$ \\
\hline \multicolumn{7}{|c|}{ Avoidance/ Reduction Strategies } \\
\hline $\begin{array}{l}\text { Message } \\
\text { Abandonment }\end{array}$ & $\begin{array}{l}\text { Leaving a message } \\
\text { unfinished because } \\
\text { of some language } \\
\text { difficulty. }\end{array}$ & $\begin{array}{l}\text { D3: ... she rand across the girl... and hug } \\
\text { her... they hug each other, then... (smiles, } \\
\text { looks at the recorder and left her seat) }\end{array}$ & 89 & $56.3 \%$ & 1 & 4.5 \\
\hline Omission & & $\begin{array}{l}\text { A5: ...I see a picture with... she have a } \\
\text { sister and he tried to... to have a... she's } \\
\text { have a diary... }\end{array}$ & 46 & $49.1 \%$ & 3 & 13 \\
\hline $\begin{array}{l}\text { Topic } \\
\text { Avoidance }\end{array}$ & $\begin{array}{l}\text { Reducing the } \\
\text { message by } \\
\text { avoiding certain } \\
\text { language } \\
\text { structures or topics } \\
\text { considered } \\
\text { problematic. }\end{array}$ & $\begin{array}{l}\text { B28: ..then ... the monster... the } \\
\text { monsss...ter...its house... }\end{array}$ & 63 & $39.9 \%$ & 2 & 8 \\
\hline
\end{tabular}


International Journal of Trend in Scientific Research and Development (IJTSRD) ISSN: 2456-6470

\begin{tabular}{|c|c|c|c|c|c|c|}
\hline \multicolumn{7}{|c|}{ Achievement / Compensatory Strategies } \\
\hline Circumlocution & $\begin{array}{l}\text { Exemplifying or } \\
\text { describing the } \\
\text { properties of the } \\
\text { target object or } \\
\text { action. }\end{array}$ & $\begin{array}{l}\text { A2: ... and it's moving and morphs into } \\
\text { something like blobs of ink come out... } \\
\text { jumping up and down... }\end{array}$ & 52 & $32.9 \%$ & 5 & 11 \\
\hline $\begin{array}{l}\text { Code } \\
\text { Switching }\end{array}$ & $\begin{array}{l}\text { Employing L1 } \\
\text { words (in this } \\
\text { case, Tandaganon } \\
\text { \& Filipino) in L2 } \\
\text { speech. }\end{array}$ & $\begin{array}{l}\text { C21:...thers's ahh... some abject... na } \\
\text { lumalabas sa notebook na... like a gel na } \\
\text { itim?... }\end{array}$ & 73 & $46.2 \%$ & 3 & 8 \\
\hline \multirow{2}{*}{$\begin{array}{l}\text { Nonlinguistic } \\
\text { Means: } \\
\text { Illustrators } \\
\text { Adaptors }\end{array}$} & $\begin{array}{l}\text { A type of gesture } \\
\text { used to illustrate } \\
\text { the verbal message } \\
\text { they accompany to } \\
\text { indicate size or } \\
\text { shape of an object. }\end{array}$ & & 55 & $34.8 \%$ & 4 & 9.5 \\
\hline & $\begin{array}{l}\text { Touching } \\
\text { behaviors and } \\
\text { movements that } \\
\text { indicate internal } \\
\text { states typically } \\
\text { related to anxiety } \\
\text { or arousal }\end{array}$ & (behavioral) & 8 & $51.9 \%$ & 2 & 11.5 \\
\hline Restructuring & $\begin{array}{l}\text { Abruptly } \\
\text { interrupting the } \\
\text { original message } \\
\text { by a more } \\
\text { convenient } \\
\text { structure. }\end{array}$ & $\begin{array}{l}\text { A2: ... and I think... she... ev...everythin } \\
\text { just over the place... } \\
\text { Development }\end{array}$ & 102 & $64.6 \%$ & 1 & 2 \\
\hline \multicolumn{7}{|c|}{ Stalling/ Time Gaining Strategies } \\
\hline Fillers & $\begin{array}{l}\text { Using } \\
\text { unlexicalized } \\
\text { filled pauses such } \\
\text { as 'umming' and } \\
\text { 'erring' or using } \\
\text { short utterances to } \\
\text { what are almost } \\
\text { like phrases, like } \\
\text { 'as a matter of } \\
\text { fact' }\end{array}$ & $\begin{array}{l}\text { B16: ...all...all his bad } \\
\text { confes...ahh...ahh... aw... all his bad... } \\
\text { ay...ay...ay...so...ay...ay...she...ay...she } \\
\text { wrote in the book... }\end{array}$ & 112 & $70.9 \%$ & 1 & 1 \\
\hline $\begin{array}{l}\text { Lengthened } \\
\text { Sound }\end{array}$ & & & 83 & $52.5 \%$ & 3 & 6 \\
\hline Repetition & $\begin{array}{l}\text { Repeating a word } \\
\text { or a string of } \\
\text { words } \\
\text { immediately after } \\
\text { they were said }\end{array}$ & $\begin{array}{l}\text { A3: ... but... and then ... she's going } \\
\text { to... am...fix the book again... }\end{array}$ & 97 & $61.4 \%$ & 2 & 3 \\
\hline \multicolumn{7}{|c|}{ Self-Monitoring } \\
\hline $\begin{array}{l}\text { Self-initiated } \\
\text { Repair }\end{array}$ & $\begin{array}{l}\text { Making self- } \\
\text { initiated } \\
\text { corrections in }\end{array}$ & $\begin{array}{c}\text { C13: ... sometimes...the voice } \\
\text { sorry...sometimes saying sorry is } \\
\text { not...ahm... a hard one... }\end{array}$ & 89 & $56.3 \%$ & 1 & 4.5 \\
\hline
\end{tabular}


International Journal of Trend in Scientific Research and Development (IJTSRD) ISSN: 2456-6470

\begin{tabular}{|c|c|c|c|c|c|c|}
\hline & $\begin{array}{l}\text { one's speech after } \\
\text { the form has been } \\
\text { uttered }\end{array}$ & & & & & \\
\hline \multicolumn{7}{|c|}{ Interactional Strategies } \\
\hline $\begin{array}{l}\text { Appeals for } \\
\text { help }\end{array}$ & $\begin{array}{l}\text { Turning to the } \\
\text { interlocutor for } \\
\text { assistance by } \\
\text { asking explicit or } \\
\text { implicit questions } \\
\text { concerning a gap } \\
\text { in the speaker's L2 }\end{array}$ & $\begin{array}{l}\text { A64: ...when the notebook } \\
\text { is...she...he...the monster...unu yadto } \\
\text { mam? }\end{array}$ & 55 & $34.8 \%$ & 2 & 9.5 \\
\hline $\begin{array}{l}\text { Expression of } \\
\text { non- } \\
\text { understanding }\end{array}$ & $\begin{array}{l}\text { Expressing that } \\
\text { one did not } \\
\text { understand } \\
\text { something } \\
\text { properly either } \\
\text { verbally or } \\
\text { nonverbally }\end{array}$ & $\begin{array}{l}\text { D51: ...then... they have a...a... they have } \\
\text { a... they have a diary?.... then what's } \\
\text { that?... }\end{array}$ & 74 & $49.4 \%$ & 1 & 7 \\
\hline \multicolumn{7}{|l|}{ Others } \\
\hline Mumbling & $\begin{array}{l}\text { Swallowing or } \\
\text { muttering } \\
\text { inaudible word/s } \\
\text { whose correct } \\
\text { from the speaker is } \\
\text { uncertain }\end{array}$ & $\begin{array}{l}\text { A47: the girl slept... (inaudible word)...on } \\
\text { the stairs...unu ba?...then she ran away... } \\
\text { nternational J ournal }\end{array}$ & 47 & $29.7 \%$ & 1 & 12 \\
\hline
\end{tabular}

The corpus revealed how the definition of each communicated strategy can be expanded based on how they were used by the respondents. To give clarity on how the researcher came up with the figures given in the table above, each category is a multiple response category; hence, the figures found within categories will not total to the number of respondents since the students have used a combination of these strategies in one decoded data. The table provides a summary of how the corpus were analyzed and are ranked based on the frequency of their appearance in the students' speech.

It is claimed in this study that the students used a combination of communication strategies to communicate the message they wanted to express, thus the definitions provided in the taxonomy of Spromberg (2011) can not be limited to its definition. Take for instance fillers as the most frequent strategy used by the respondents across categories; fillers according to Spromberg's (2011) are used as pauses to rethink. Rephrase or enhance messages. But if closely evaluated, it can be seen in the sample responses that fillers (filled and unfilled) appeared in almost all sample responses including in the reduction strategies. Fillers were also used to avoid certain parts of the prompt which the students thought were difficult parts to structure a sentence. While the prompt continues to move along its plot, the respondents continue to use the fillers, some lengthening the sound of that filler, so that they could skip saying anything about what they saw from the prompt.

However, how fillers generally appeared in the corpus revealed consistency of Spromberg's definition of how fillers likely appear in regulating and modifying speech. As said already, fillers appear in most of the samples given in the table above. They are used while restructuring messages, when nonlinguistically illustrating something related to their message, when self-correcting their speech, and more.

While in an initial account of the corpus, it was presumed that code switching from L2 to L1 might result to the dominant communication strategy during the entire course of data gathering. However, the students' willingness to get their messages across put them at a stance where they could regulate and modify their utterances using communication strategies. However, it was through the focused group discussion that they were not aware that what they 
were doing were strategies as they appeared to be a natural response, seemingly like signals coming from the brain that required them to actually say something because they were asked and expected to (say something). Going into the specific categories, there are six categories of strategies which were found in the corpus: reduction strategies, compensatory strategies, stalling strategies, self-monitoring, interactional strategies, and 'mumbling', identified using the taxonomy of communication strategies of Celce-Murcia, Dirneyei, and Thurell (1995) and Dorneyei and Scott (1998).

Reduction strategies, according to Oxford (1985), is 'tailoring one's message according to one's resources.' It can then be expected that produced speech is rather limited and restricted since the speaker will rely on the what is and how much is available in his linguistic resources. Reduction can come in three varieties, either abandoning the message, omitting parts of the message, and avoiding topics. Based on the tabular presentation, message abandonment can be seen as the dominant strategy for this category. Message abandonment is leaving a thought hanging caused by unfinished messages. The inability to finish the message can either be intentional or unintentional and is caused by lacking or deficit in resource. In the sample given above, the message was left 'intentionally' hanging after realizing that it was difficult to explore his resources and experiment on structures which was contributory to the reason why respondent D3 was not able to finish his sentence. In other cases, a message can be abandoned after realizing that another available linguistic resource can be used, thus the original message is dropped and then modified my restructuring it. The appearance of this strategy can also be associated to anxiety often experienced by speakers who are asked to produce utterances using a language which they lack mastery other than their L1. Refusing to take risks can save them the negative feedback that they might get as a result of saying erroneous and unspontaneous speech.

Restructuring on the other hand, is a compensatory strategy which comes as the second dominant strategy across categories. Compensatory strategies are tools that enable learners to use the new language for production despite limitations in the knowledge (Oxford, 1985). Risk taking is more likely the stance of the speakers who use these strategies. Based on the samples given in the table, restructuring appeared after abandoning the original message for a new structure or after a self-initiated repair. Restructuring message was also paired with fillers, illustrators, and other gestures. The use of this strategy can be viewed as an optimistic approach in the speech making process.

On the third category, self-initiated repair is the only sub strategy labelled under monitoring strategy. According to Griffith (2004), there are three types of knowledge: knowledge of underlying grammatical principles, knowledge of how to use language in a social context to fulfill communicative functions and knowledge of how to combine utterances and communicative functions on discourse principles. Self-initiated repair comes in one of these defined knowledges. In addition, Dorneyei and Scott (1995) defines self-initiated repairs as strategies that manifests the speakers; knowledge of the structure and form of the language. Such knowledge enables speakers to instantaneously resolve errors and correct them' after realizing that they have committed errors in their utterance either structure or form, or both.

Expressing non-understanding of the contents given in the prompt came in as first in the interactional strategies category. Perhaps seeing the prompt for the first time, aside from the fact that they already lacked mastery of the rules of the language they were asked to use in the activity, was another contributory factor as to why $49.4 \%$ of the 158 respondents did not understand why and how things came to happen in the prompt given to the, as basis for the corpus. While in some cases, some students chose to appeal for help by directly asking explicit questions like, "unu yadto mam?" or simply translated as "what was it ma'am?", some stick to their wit and ability to get through their task on their own. Based on the account of respondent D51, he was too shy to ask anything and chose to work on the confusion on his own.

Lastly, is 'mumbling' which is listed as 'other' category of communication strategy. It is perhaps difficult to list this strategy under the other existing categories since it is neither avoidance or reduction since the speaker chose to say something about an action or description of something; nor is it a compensatory strategy since the speaker was not able to get through his message because he left a portion of his utterance inaudible, leaving it a puzzle, nor is it a stalling strategy since it was not used to rethink or restructure, nor an interaction since it was not 
provoking a response from the recorder. In the example given, it would seem that respondent A47 has committed an error in either the lexis 'slept' or in pronunciation of a target word since there was the mention of 'stairs', he would have perhaps wanted to correct something but since he was not so sure about how to correct it, he continues to speak, however making that portion of his speech inaudible.

\section{Conclusion}

Chomsky (1965) defined 'competence' as the underlying knowledge that enables the use of a language and understand a set of rules. In de Sausure's terms, he coined it 'langue' which refers to the psychological part of the circuit, in this case on strategic competence, it refers to the knowledge of solving problems in communication. To prove that ability, Sausure maintained he coined the term 'parole' to refer to the executive component of one's knowledge. In Chomksy's distinction, he called it performance which refers to the application of the underlying competence or knowledge, particularly for this study on strategic competence, in solving problems in communication.

Communication strategies manifests the students' strategic competence as part of their competence in communication. How they appeared in the speechmaking process provides a consistent evidence to Celce-Murcia's, Dorneyei's and Scott's that strategic competence is an independent dimension of communicative competence. Strategic competence appears where other dimensions of communicative competence (linguistic, sociolinguistic, and discourse) are lacking and limited, allowing speakers to modify and regulate speech in communication. Based on the findings that were revealed through the analysis of the corpus, some communication strategies can be more than how they are defined in existing definitions with respect to how they are used by speakers. Also, strategies can be used in combination with other sub strategies to get through a task in communication.

\section{References}

1. Asuncion, Z. (2010). Filipino college freshman students' oral compensatory strategies. Philippine esl journal, vol. 5, july 2010.

2. Bautista, R. (2014). Determinants of students' communication strategies in science classes. European journal of english language and linguistics research, vol.2, no.4, 2014
3. Cabaysa (2010). Language learning strategies of students at different levels of speaking proficiency. Education quarterly, vol 68, december 2010

4. Cabaysa, A. and Baetiong, M. (2015). Non-native english students learning in english: reviewing and reflecting on the research. De La Salle University, Philippines. Retrieved: 11July2016 from,

http://www.nus.edu.sg/celc/research/books/3rdsy mposium/01-bernardoREV.pdf

5. Castillo, R. (2013). Strategic knowledge and strategic competence. University of the Visayas, Philippines. Science Direct: Procedia-Social and Behavioral Sciences. Retrieved: 10July2016 from, http://ac.els-cdn.com/S187704281403153X/1s2.0-S187704281403153X-main.pdf

6. Celce-Murcia, et al. (1995). Communicative competence: a pedagogically motivated model with content specifications. Issues in Applied Linguistics. ISSN 1050-4273. Vol. 6 No.2.

7. Griffiths, C. (2004). Language learning strategies: theory and research. Journal of the Association for Communication Administration. 29 (2000), 1-25

8. Hans, A and Hans, E. (2015). Kinesics, haptics and proxemics: aspects of non-verbal communication. IOSR journal of humanities and social science, vol. 20, feb 2015._is_Important_\%20Rationale_for_Centrality _of_the_Study_of_Communication.pdf

9. Karon, J. (2012). Communication strategies applied by polish intermediate users of englishthe results of a pilot study. Prace naukowe akademii im. 2012

10. Huang, J. (2010). Critical thinking in the language classroom. Retrieved: 10July2016 from, http://www.ettoi.pl/PDF_resources/Critical_Think ingENG.pdf :11July2016 from, http://www.bjournal.co.uk/paper/bjass_2_1/bjass_ 02_01_04.pdf

11. Rahman, M.M. (2010). Teaching oral communication skills: a task-based approach. esp world issue 1 (27), Volume 9. Retrieved: 10July2016 from, http://www.espworld.info/Articles_27/Paper.pdf

12. Spromberg, S (2011). Communication strategies used by high school english language learners in multilingual classrooms. Curriculum for english 
International Journal of Trend in Scientific Research and Development (IJTSRD) ISSN: 2456-6470

language development in universities and institutes, british council, ministry of education of Ukraine.

13. Seong, Y. (2014). Strategic knowledge and strategic competence. Translation Journal, Vol.
17, No.1. Institute of Fundamental Education, Ural Federal University B.N. yeltsin, Russia. Retrieved: 10July2016 from, http://translationjournal.net/journal/63learning.ht $\mathrm{m}$

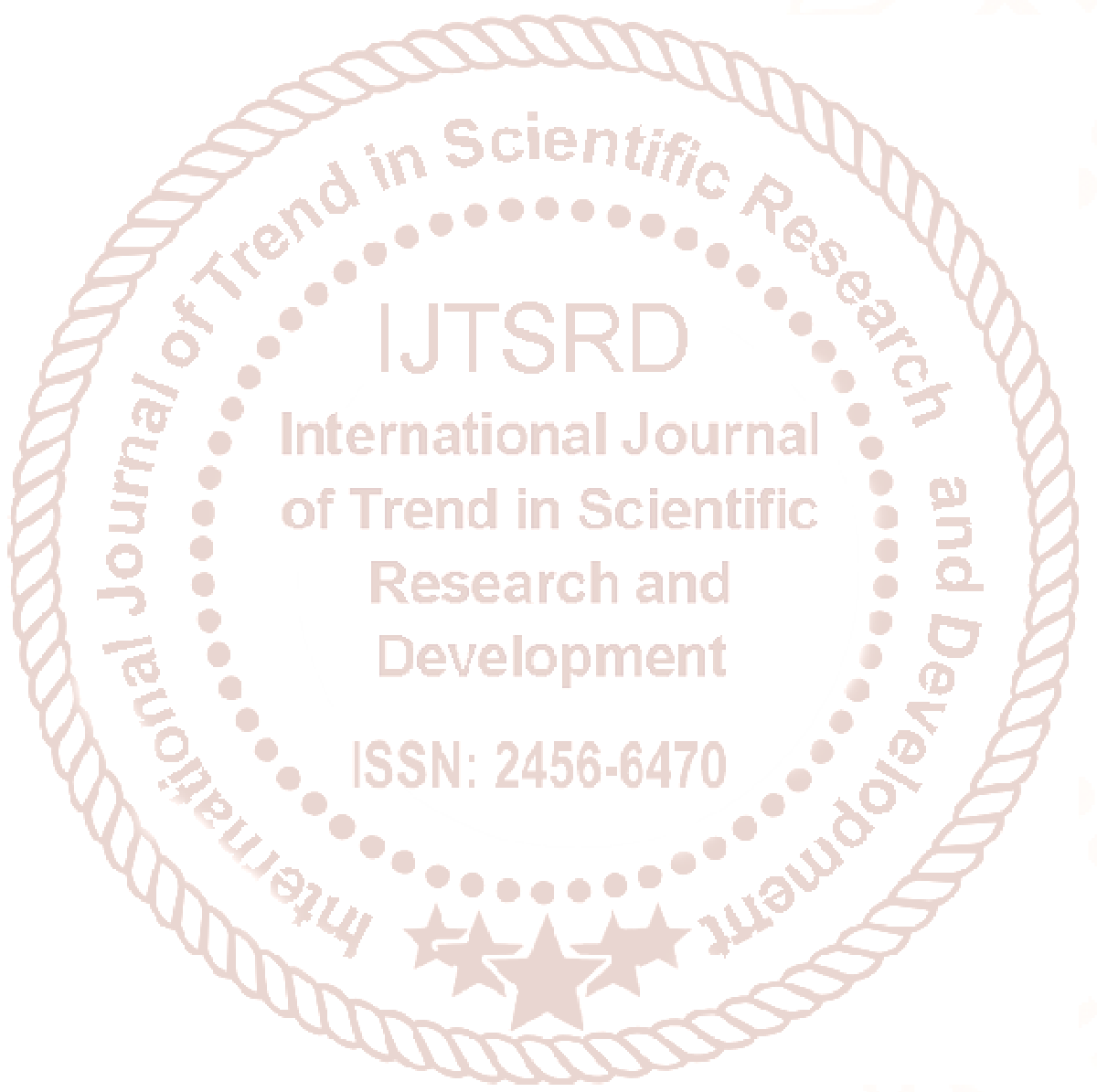

